Sains Malaysiana 48(1)(2019): 81-91

http://dx.doi.org/10.17576/jsm-2019-4801-10

\title{
The Escherichia coli motA Flagellar Gene as a Potential Integration Site for Large Synthetic DNA
}

(Gen Flagelum Escherichia coli motA sebagai Tapak Integrasi yang Berpotensi untuk DNA Sintetik Besar)

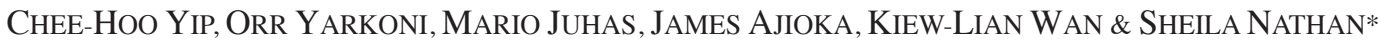

\begin{abstract}
Escherichia coli is used as a chassis for many synthetic biology applications. However, the limitations of maintaining recombinant plasmids extra-chromosomally include increased metabolic burden to the host, constant selective pressure, variable plasmid copy number and plasmid instability that leads to curing. Hence, to overcome these limitations, DNA constructs are integrated into the bacterial chromosome to allow stable control of copy number and to reduce the metabolic burden towards the surrogate host. Non-essential E. coli flagellar genes have been proposed as potential chromosomal insertion target sites. In this study, we validated and compared the efficiency of two loci, namely motA and $\mathrm{flgG}$, as target sites for synthetic biology applications. To enable this comparison, a dual reporter strain (DRS) that utilises two reporter proteins, EforRED and Venus, was developed as a test case. Initially, a yellow reporter plasmid k14.1_Venus was constructed and subsequently used as the plasmid backbone for the generation of two other plasmids, k14.1_eforRED and pcat_Venus, required to build the dual reporter strain. In the DRS, the eforRED gene was inserted into flgG whereas motA was disrupted by Venus. This mutant strain was defective in motility $(\mathrm{p}<0.001)$ but growth rate was unaffected. The fluorescence emitted by Venus was higher $(\mathrm{p}<0.05)$ compared to EforRED, suggesting that motA is the better chromosomal target locus compared to flgG. Hence, this study proposes the use of $\mathrm{E}$. coli motA as the site for chromosomal insertion for future synthetic biology applications.
\end{abstract}

Keywords: Chromosomal integration; protein expression; reporter system; synthetic biology

\section{ABSTRAK}

Bakteria Escherichia coli digunakan sebagai kes dalam banyak aplikasi biologi sintetik. Walau bagaimanapun, cabaran untuk mengekalkan plasmid rekombinan di luar kromosom termasuk peningkatan beban metabolik kepada perumah, tekanan memilih yang berterusan, pelbagai bilangan salinan plasmid dan ketidakstabilan plasmid membawa kepada penyingkiran plasmid daripada bakteria. Untuk mengatasi batasan tersebut, binaan DNA diintegrasikan ke dalam kromosom bakteria untuk membenarkan bilangan salinan gen yang terkawal dan mengurangkan beban metabolik kepada perumah pengganti. Gen flagelum yang tidak perlu telah dicadangkan sebagai tapak sasaran penyisipan kromosom yang berpotensi. Dalam kajian ini, kami mengesah dan membandingkan kecekapan dua lokus, iaitu motA dan flgG, sebagai tapak sasaran untuk aplikasi biologi sintetik. Untuk membenarkan perbandingan ini, strain dwipelapor (DRS) yang menggunakan dua protein pelapor, EforRED dan Venus, telah dibangunkan sebagai kes ujian. Pada mulanya, plasmid pelapor kuning, k14.1_Venus dibina dan kemudiannya digunakan sebagai tulang belakang plasmid untuk menjana dua plasmid lain, k14.1_eforRED dan pcat_Venus, yang diperlukan untuk membina DRS. Dalam DRS, gen eforRED diselitkan ke dalam $\mathrm{flgG}$ manakala motA disisip dengan Venus. Kemortilan strain mutan ini dimansuhkan $(\mathrm{p}<0.001)$ tetapi kadar pertumbuhannya tidak terjejas. Pendarfluor yang dipancarkan oleh Venus lebih tinggi ( $\mathrm{p}<0.05)$ berbanding dengan EforRED, menunjukkan bahawa motA merupakan lokus sasaran kromosom yang lebih baik berbanding dengan flgG. Oleh itu, kajian ini mencadangkan penggunaan E. coli motA sebagai tapak untuk penyisipan kromosom dalam aplikasi biologi sintetik pada masa depan.

Kata kunci: Biologi sintetik; integrasi kromosom; pengungkapan protein; sistem pelapor

\section{INTRODUCTION}

Synthetic biology is a new way of doing biological sciences by enabling high-level synthesis of products from DNA constructs or modified pathways. It holds great potential in engineering complex biological systems for the synthesis of many useful products such as drugs, polymers, food, biomass and fuels (Haseloff \& Ajioka 2009). Examples of products derived using the synthetic biology platform include the antimalarial artemisinin (Keasling 2008), terpenoids (Chang et al. 2007) and green biofuels (Atsumi et al. 2008). Synthetic DNA constructs or pathways are inserted into Escherichia coli which is routinely used as an intermediate or final chassis (Ajikumar et al. 2010; Juhas 2016; Juhas et al. 2013).

However, the introduction of extrachromosomal recombinant plasmids into $E$. coli for the synthesis of 
desired products usually imposes a high metabolic burden onto the host as well as constant selective pressure to avoid plasmid curing as a result of plasmid instability (Cunningham et al. 2009). The quality and stability of extrachromosomal plasmids are dependent on active cell machinery for its synthesis while plasmid maintenance can elicit stress responses from the surrogate host that will lead to plasmid instability (Silva et al.2012). In a previous study, a medium-copy recombinant plasmid was cured after the 35th generation and the host lost the ability to synthesise polyhydroxybutyrate (PHB) even in the presence of antibiotics, however, the marker-free host with the gene of interest inserted into the bacterial chromosome was able to produce PHB stably for an extended period of time (Tyo et al. 2009). Furthermore, a high copy number plasmid does not necessarily guarantee increased protein expression. A strain with six integrated gene copies could synthesise more L-serine compared to a strain harbouring a medium-copy (15-20 copies) recombinant plasmid. This is due to saturation of extrachromosomal plasmids in the cell, leading to host metabolic burden and a decrease in protein synthesis (Gu et al. 2015).

To overcome these drawbacks, synthetic DNA constructs are preferably integrated into the host chromosome to generate marker-free strains to lower host metabolic burden and enable controlled copy number and stable DNA propagation. Previously, flagellar genes in regions 1 (Juhas \& Ajioka 2015a), 2, 3b (Juhas \& Ajioka 2015b) and 3a (Juhas et al.2014) of the E. coli chromosome were identified as potential sites for DNA integration due to high level of RNA polymerase binding to these regions (Juhas et al. 2014).
The flagellar regions were identified as loci harbouring nonessential flagellar genes of $E$. coli that have high expression under laboratory conditions (Juhas et al. 2014). Integration of simple genetic circuits into the flagellar genes did not have a negative impact on the growth of the host (Juhas \& Ajioka 2015a, 2015b; Juhas et al. 2014). Of all the tested genes, $f g G$ of region 1 (Juhas \& Ajioka 2015a) and mot A of region 2 (Juhas \& Ajioka 2015b) were deemed the most suitable integration target loci for chromosomal insertion.

Hence, in this study, we set out to determine whether $\operatorname{fgG}$ or motA was the better integration site for large DNA constructs. To achieve this, a dual reporter system (DRS) that utilises the red (eforRED) and yellow (Venus) reporter genes was used as proof-of-concept. Prior to the system development, a yellow reporter plasmid, k14.1_Venus was first constructed and used as the plasmid backbone for the development of two other reporter plasmids, k14.1_eforRED and pcat_Venus. These two plasmids were then used as the templates for the generation of recombineering cassettes for Red recombinase-based chromosomal integration to build the DRS. Bacterial growth and fluorescence emitted of the individual strains were evaluated to determine the better integration target site.

\section{MATERIALS AND METHODS}

\section{BACTERIAL STRAINS, PLASMIDS AND GROWTH CONDITIONS}

The bacterial strains and plasmids used in this study are listed in Table 1. Luria Bertani (LB) agar supplemented

TABLE 1. Bacterial strains and plasmids used in this study

\begin{tabular}{|c|c|c|}
\hline & Characteristics & Source \\
\hline \multicolumn{3}{|l|}{ Bacterial strains } \\
\hline E. cloni $^{\circledR} 10 \mathrm{G}$ & 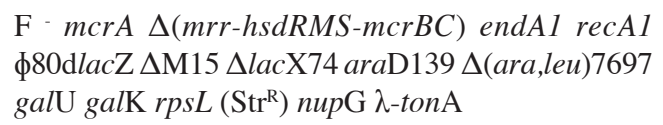 & Lucigen, USA \\
\hline One Shot ${ }^{\circledR}$ BL21 Star ${ }^{\mathrm{TM}}$ (DE3) & $\begin{array}{l}\mathrm{F}^{-} \text {ompT hsdSB (rB-mB') gal dcm (DE3) pLysS } \\
(\mathrm{CamR})\end{array}$ & Invitrogen, USA \\
\hline \multicolumn{3}{|l|}{ Plasmids } \\
\hline pJS209_eforRED & $\beta$-lactamase FRT cassette with eforRED in $\mathrm{pSB} 1 \mathrm{~K} 3$ & $\begin{array}{l}\text { Department of Pathology, University of } \\
\text { Cambridge (DPUC) }\end{array}$ \\
\hline pLysS & $\begin{array}{l}\text { chloramphenicol acetyltransferase cassette with } \mathrm{T} 7 \\
\text { lysozyme gene }\end{array}$ & Invitrogen, USA \\
\hline $\mathrm{k} 14.1$ & kanamycin FRT cassette in $\mathrm{pSB} 1 \mathrm{~K} 3$ & DPUC (Juhas et al. 2014) \\
\hline k14.1_pJS209 & $\begin{array}{l}\text { kanamycin FRT and } \beta \text {-lactamase cassette with Venus } \\
\text { in pSB1K3 }\end{array}$ & DPUC \\
\hline k14.1_Venus & kanamycin FRT cassette with Venus in pSB1K3 & This study \\
\hline k14.1_eforRED & kanamycin FRT cassette with eforRED in $\mathrm{pSB} 1 \mathrm{~K} 3$ & This study \\
\hline pcat_Venus & $\begin{array}{l}\text { chloramphenicol acetyltransferase FRT cassette with } \\
\text { Venus in pSB } 1 \mathrm{~K} 3\end{array}$ & This study \\
\hline pKM208 & Red recombinase controlled by lac $Z$ & DPUC (Murphy \& Campellone 2003) \\
\hline pCP20 & FLP recombinase helper plasmid & DPUC (Datsenko \& Wanner 2000) \\
\hline
\end{tabular}


with $100 \mu \mathrm{g} / \mathrm{mL}$ carbenicillin, $50 \mu \mathrm{g} / \mathrm{mL}$ kanamycin or $35 \mu \mathrm{g} / \mathrm{mL}$ chloramphenicol when required, was used to cultivate the $E$. coli strains. The plate cultures were grown aerobically for $16 \mathrm{~h}$ at either $30^{\circ} \mathrm{C}$ or $37^{\circ} \mathrm{C}$. The E. coli liquid cultures were grown in LB and incubated at 250 r.p.m. for $16 \mathrm{~h}$ at either $30^{\circ} \mathrm{C}$ or $37^{\circ} \mathrm{C}$.

\section{PRIMERS}

The primers used in this study were designed based on the DNA sequence of the templates. The melting temperature and secondary structure formation of each primer was evaluated using OligoAnalyzer 3.1 (https://sg.idtdna. com/calc/analyzer). These primers were synthesised by Integrated DNA Technology (USA).

\section{PCR AMPLIFICATION AND DNA MODIFICATIONS}

The plasmid k14.1_pJS209 (University of Cambridge) was used as the template for the amplification of the yellow reporter gene, Venus, using the Venus primers (Table 2) whereas plasmid k14.1 (Juhas et al. 2014) was linearised using the k14.1 primers (Table 2). Polymerase chain reaction (PCR) was performed in a total reaction volume of $25 \mu \mathrm{L}$ using Q ${ }^{\circledR}$ High Fidelity Polymerase (New England BioLabs) according to the supplier's instructions. The amplicons (k14.1 and Venus) were electrophoresed and purified using the Qiaquick Gel Extraction Kit (Qiagen). Gel purification was carried out according to the supplier's instructions with slight modifications. The modifications made to the standard protocol were to replace the single 750 $\mu \mathrm{L}$ wash of Buffer PE with two washes of $600 \mu \mathrm{L}$ and 400 $\mu \mathrm{L}$ and also, a total of $14 \mu \mathrm{L}$ of Buffer EB was added instead of $50 \mu \mathrm{L}$. Incubation at room temperature was increased to $5 \mathrm{~min}$ and this was repeated twice. The concentrations of the amplicons were evaluated on a spectrophotometer (NanoDrop 2000c, Thermo Fisher Scientific Inc.).

\section{GIBSON CLONING TO ASSEMBLE K14.1_VENUS}

A modified Gibson Assembly was used to ligate the gene of interest into the plasmid backbone (Gibson et al. 2009). For the construction of k14.1_Venus, equimolar of k14.1 and Venus $\left(3.7 \times 10^{-5} \mathrm{nmol}\right)$ were added to $4 \mu \mathrm{L}$ of 1.33× Gibson Master Mix consisting of $5 \times$ isothermal buffer, T5 exonuclease, Taq ligase, Phusion polymerase

TABLE 2. Primers used in this study

\begin{tabular}{|c|c|}
\hline Primers & Sequence $(5, \circledR 3$ ') \\
\hline k14.1_F & TTTACAGCTAGCTCAGTCCTAGG \\
\hline k14.1_R & TGAGAATTAATTCCGGGGATC \\
\hline eforRED_F & CTTCGAACTGCAGGTCGACGGATCCCCGGAATTAATTCTCATTCAGAACGCTCGGTTGCC \\
\hline eforRED_R & TAGCATAATACCTAGGACTGAGCTAGCTGTAAAGAGAGCGTTCACCGACAAACAACAGAT \\
\hline openk14.1_Venus_eforRED_F & ATCTGTTGTTTGTCGGTGAACGCTCTCTTTACAGCTAGCTCAGTCCTAGGTATTATGCTA \\
\hline openk14.1_Venus_eforRED_R & GGCAACCGAGCGTTCTGAATGAGAATTAATTCCGGGGATCCGTCGACCTGCAGTTCGAAG \\
\hline Venus_F & CTTCGAACTGCAGGTCGACGGATCCCCGGAATTAATTCTCATTCAGAACGCTCGGTTGCC \\
\hline Venus_R & CTAGCATAATACCTAGGACTGAGCTAGCTGTAAAGAGAGCGTTCACCGACAAACAACAGA \\
\hline openk14.1_Venus_cat_F & TGGTGAAAGTTGGAACCTCTTACGTGCCGAGCGAAACGATCCTCATCCTGTCTCTTGATC \\
\hline openk14.1_Venus_cat_R & ATGAGCAAACTGAAACGTTTTCATCGCTCTATAAGGGGATCTTGAAGTTCCTATTCCGAA \\
\hline cat_F & TTCGGAATAGGAACTTCAAGATCCCCTTATGTCGAATTTGCTTTCGAATTTCTGCCATTC \\
\hline cat_R & GATCAAGAGACAGGATGAGGATCGTTTCGCTCGGCACGTAAGAGGTTCCAACTTTCACCA \\
\hline motA_F & $\begin{array}{l}\text { CTCCAAATACACCAAAGCAATGTATATGGATCTGCTGGCTCTGCTTTATCGGTTGATGGCGAA } \\
\text { ATCGTATCACGAGGCAGAATTTCAGAT }\end{array}$ \\
\hline motA_R & $\begin{array}{l}\text { TTTCTGACGTAAAACAGTCGCTAATGGGGAAATAAATCCGTAAGCCAATAAAATGCCGAGGA } \\
\text { AAGTCGGTTTTAAAGAAAAAGGGCAGG }\end{array}$ \\
\hline$f l g G_{-} \mathrm{F}$ & $\begin{array}{l}\text { TTTGTCACTAATCCACTACAGGACATTTTATGATCAGTTCATTATGGATCGCCAAAACGGGCCT } \\
\text { TGGTATCACGAGGCAGAATTTCAGAT }\end{array}$ \\
\hline$f l g G_{-} \mathrm{R}$ & $\begin{array}{l}\text { CACCTGAATCATATTGACCAGTTCTTCCGCCACGTTGACGTTAGACGTTTCAACATACCCTTG } \\
\text { ATACGGTTTTAAAGAAAAAGGGCAGG }\end{array}$ \\
\hline motAi_F & GGGTCGTTTATCGTCGGCAATAATGGCAAAGCGATTAAAGGCACGCTGAA \\
\hline motAi_R & GAAAGCAGAGTGACTTTGACGCACTGCATCATTTTGCTGGTTTCGGCGCT \\
\hline flgGi_F & GAAAGGATACATGACAAGTATAAGTTGCCCGATGCGCAAGTTTATCGGGT \\
\hline flgGi_R & CCGGTTAAGCCTTAGAGTTGCGTCAGTTTTTGCAGCATCTGATCGGTGGT \\
\hline FRT_F & GATTGCAGCATTACACGTCTTGAGCGATTGTGTAGGCTGGAGCTGCTTCG \\
\hline FRT_R & TGAGAATTAATTCCGGGGATCCGTCGACCTGCAGTT \\
\hline
\end{tabular}


and nuclease-free water (https://openwetware.org/wiki/ Gibson_Assembly). The reaction mixture was incubated at $50^{\circ} \mathrm{C}$ for $60 \mathrm{~min}$.

\section{TRANSFORMATION OF RECOMBINANT PLASMIDS INTO CHEMICALLY COMPETENT E. COLI}

Chemically competent $E$. coli $E$. cloni $10 \mathrm{G}$ was prepared using the ССMB80 buffer (Hanahan et al. 1991). One microliter of the Gibson assembly reaction was added into a vial of $100 \mu \mathrm{L}$ of chemically competent $E$. coli and incubated on ice for $30 \mathrm{~min}$. The vial of cells was heat-shocked at $42^{\circ} \mathrm{C}$ for $30 \mathrm{~s}$ followed by immediate incubation on ice for $2 \mathrm{~min}$. A total of $250 \mu \mathrm{L}$ of Super Optimal broth with catabolite repression (SOC) medium at room temperature was added into the bacterial mixture and recovered by horizontal shaking at $37^{\circ} \mathrm{C}$ for $1 \mathrm{~h}$ before plating on LB agar with $50 \mu \mathrm{g} / \mathrm{mL}$ kanamycin. The transformants were grown for $16 \mathrm{~h}$ at $37^{\circ} \mathrm{C}$.

\section{VERIFICATION OF K14.1 VENUS}

Colonies that grew on the kanamycin selective plates and emited yellow fluorescence when observed under UV light were picked and inoculated into LB with kanamycin. The liquid culture was grown for $16 \mathrm{~h}$ at $37^{\circ} \mathrm{C}$ and 250 r.p.m. Plasmids were prepared using the Qiaprep Spin Miniprep Kit (Qiagen) with the time of incubation at room temperature increased from 1 to $5 \mathrm{~min}$ and the incubation was done twice. The recombinant plasmid was then sent to Source Bioscience (UK) for DNA sequencing. Sequence analysis was performed using the A plasmid Editor (ApE) software (Davis 2012).

\section{CONSTRUCTION OF k14.1_eforRED AND pcat_Venus}

PCR amplifications were performed using Q5 ${ }^{\circledR}$ HighFidelity Polymerase (New England Biolabs). The plasmid k14.1_Venus was used as the plasmid backbone for the construction of k14.1_eforRED and pcat_Venus. In the construction of k14.1_eforRED, plasmid k14.1_Venus was linearised using the openk14.1_Venus_eforRED primers (Table 2). The plasmid pJS209_eforRED was used as the template for the amplification of the red reporter gene, eforRED, using the eforRED primers (Table 2). The openk14.1_Venus_cat primers (Table 2) were used to linearise k14.1_Venus to exclude the kanamycin (kan) cassette. Plasmid pLysS was extracted from $E$. coli BL21 STAR $^{\text {TM }}$ (DE3) using the Qiaprep Spin Miniprep Kit (Qiagen) and used as template for the amplification of the chloramphenicol acetyltransferase (cat) gene using the cat primers (Table 2). The amplicons were gel-purified before their concentrations were determined using a spectrophotomer ((NanoDrop 2000c, Thermo Fisher Scientific Inc.).

Equimolar of linearised k14.1 and eforRED (3.0 $\times 10^{-5} \mathrm{nmol}$ ) or linearised k14.1_Venus (kan cassette excluded) and cat gene $\left(3.4 \times 10^{-5} \mathrm{nmol}\right)$ were added to $4 \mu \mathrm{L}$ of $1.33 \times$ Gibson Master Mix prior to incubation at $50^{\circ} \mathrm{C}$ for $60 \mathrm{~min}$. One microliter of each assembly reaction was transformed into E. coli E. cloni $10 \mathrm{G}$ by heat shock. Transformants were selected on $50 \mu \mathrm{g} / \mathrm{mL}$ kanamycin (k14.1_eforRED transformants) or $35 \mu \mathrm{g}$ / $\mathrm{mL}$ chloramphenicol (pcat_Venus transformants) plates. Culture plates were grown at $37^{\circ} \mathrm{C}$ and antibiotic resistant colonies that fluoresced under UV light were subjected to colony PCR using GoTaq Polymerase (Promega) according to the supplier's information in a final volume of $25 \mu \mathrm{L}$. The PCR programme performed was as recommended by the supplier except that a cell lysis step at $98^{\circ} \mathrm{C}$ for $10 \mathrm{~min}$ was included in the beginning of the protocol. Plasmids of the positive transformants were sequenced and sequences were analysed with the ApE software.

\section{AMPLIFICATION OF $f g G$-eforRED AND motA-Venus RECOMBINEERING CASSETTES}

Plasmid k14.1_eforRED was used as the template to generate the recombineering cassette flgG-eforRED whereas plasmid pcat_Venus was the template used to amplify the motA-Venus cassette. The $\lg G$ and motA flanking homologous sequences for site-directed Red recombinase-based chromosomal integration were fused to the reporter genes using the $f g G$ and $\operatorname{mot} A$ primers (Table 2), respectively. PCR was carried out using Q5 ${ }^{\circledR}$ High-Fidelity Polymerase (New England Biolabs) and the concentrations of the gel-purified products were determined by spectrophotometry.

\section{TRANSFORMATION OF PCR PRODUCTS INTO ELECTROCOMPETENT E. COLI}

Electrocompetent E. coli E. cloni $10 \mathrm{G}$ was prepared using the modified protocol of Juhas et al. (2014). The $E$. coli was electroporated with pKM208 (expressing the $\lambda$ Red recombinases for chromosomal insertion) in a $2 \mathrm{~mm}$ electroporation cuvette (Sigma-Aldrich) in the Bio-Rad micropulser at $2.5 \mathrm{kV}, 200 \Omega$ and $25 \mu \mathrm{F}$ for 5 miliseconds, recovered and selected on plates with 100 $\mu \mathrm{g} / \mathrm{mL}$ of carbenicillin at $30^{\circ} \mathrm{C}$. A carbenicillin resistant colony was inoculated into $\mathrm{LB}$ with $100 \mu \mathrm{g} / \mathrm{mL}$ of carbenicillin and grown overnight at $30^{\circ} \mathrm{C}$ and 250 r.p.m. One mililiter of the overnight culture was diluted (1:100 dilution) using LB with $100 \mu \mathrm{g} / \mathrm{mL}$ carbenicillin and grown at $30^{\circ} \mathrm{C}$ and 250 r.p.m. to $\mathrm{OD}_{600}=0.2$. Isopropyl $\beta-\mathrm{D}-1-$ thiogalactopyranoside (IPTG, $1 \mathrm{mM}$ ) was added and the culture was grown to an $\mathrm{OD}_{600}$ of 0.5 . The E. coli cells were harvested by centrifugation at $5500 \times \mathrm{g}$ and $4^{\circ} \mathrm{C}$ for 15 min and washed with $10 \%$ (v/v) chilled glycerol. The centrifugation and washing steps were repeated twice prior to resuspending the cells in a final volume of 100 $\mu \mathrm{L}$ of $10 \%$ chilled glycerol. Fourteen microliters of the gel-purified $\operatorname{fg} G$-eforRED ( 4 $\mu$ g of DNA) was added into a vial of electrocompetent cells and electroporation was carried out using the electroporation settings described above. Transformants were selected on kanamycin and carbenicillin double selection plates and grown at $30^{\circ} \mathrm{C}$ for $16 \mathrm{~h}$. 
VERIFICATION OF CHROMOSOMALLY INSERTED EFORRED AND REMOVAL OF ANTIBIOTIC RESISTANCE GENE

The kanamycin and carbenicillin resistant colonies were grown on LB agar without antibiotics at $42^{\circ} \mathrm{C}$ for $16 \mathrm{~h}$ to cure pKM208 and subsequently, tested for kanamycin and carbenicillin sensitivity. Colonies resistant to kanamycin but not carbenicillin were picked for colony PCR. The chromosomally integrated transformants were verified with flanking $f g G$ primers (Table 2) using GoTaq Polymerase (Promega) and the PCR samples were run on a $2 \%$ agarose gel. Successful chromosomally integrated colonies were made electrocompetent as described by the method above, without the addition of $1 \mathrm{mM}$ IPTG. The thermosensitive plasmid pCP20 that harbours the $f p$ gene encoding Flip recombinase (FLP) was transformed into the electrocompetent cells. Transformants were selected on carbenicillin plates and grown for $16 \mathrm{~h}$ at $30^{\circ} \mathrm{C}$. Carbenicillin resistant colonies were grown for $16 \mathrm{~h}$ at $42^{\circ} \mathrm{C}$ to cure pCP20 and tested for sensitivity towards kanamycin and carbenicillin. Colonies that were sensitive to both antibiotics were subjected to colony PCR. A colony PCR with flanking FRT primers (Table 2) using GoTaq Polymerase (Promega) was performed and the amplicons were electrophoresed on $2 \%$ agarose gel. The chromosomally integrated eforRED transformant strain with a successfully knocked-out kan was named $f g G \mathrm{i}$ eforRED.

\section{DEVELOPMENT OF THE DUAL REPORTER SYSTEM}

The dual reporter system was developed by integrating the motA-Venus recombineering cassette into the chromosomal motA site (motAi Venus) of flgGi eforRED strain and subsequently, cat cassette removal using the same method as described above. In parallel, the construction of the marker-free reverse dual reporter system (motAi eforRED and $f g G \mathrm{i}$ Venus) was attempted following the methods as described before for the development of the dual reporter system.

\section{SWIMMING ASSAY}

An overnight bacterial culture of wild-type $E$. coli $E$. cloni 10G, flgGi eforRED and DRS were normalised to an $\mathrm{OD}_{600}$ of 0.5 before $1 \mu \mathrm{L}$ of culture was inoculated into the bottom of pre-set swimming agar $(0.3 \% ; 10 \mathrm{~g}$ tryptone, $5 \mathrm{~g}$ $\mathrm{NaCl}, 0.3 \%$ Bacteriological Agar (Pronadisa)) plates. The assay was carried out with three biological replicates. The plates were incubated at $37^{\circ} \mathrm{C}$ for $48 \mathrm{~h}$ and the diameter of the swimming halo formed was measured. Statistical significance ( $p$-value) in the size of halo formed between mutant and wild-type strains was calculated using the paired sample Student's t-test (Microsoft Excel 2013).

\section{MEASUREMENT OF BACTERIAL GROWTH AND VENUS AND EFORRED FLUORESCENCE}

Growth and fluorescence were measured based on optical density readings of three biological replicates and three technical replicates each. The wild-type E. coli E. cloni $10 \mathrm{G}$ and DRS were grown overnight to stationary phase and normalised to $\mathrm{OD}_{600}$ of 0.05 using LB broth. One mililiter of the bacterial cultures and LB medium (blank) were loaded into $10 \mathrm{~mm}$ cuvettes (Greiner Bio-One). The optical densities of EforRED and Venus were measured at excitation wavelengths of $589 \mathrm{~nm}$ and $515 \mathrm{~nm}$, respectively, whereas cell density of the strain was measured at $600 \mathrm{~nm}$. Fluorescence and cell absorbance were measured using spectrophotometry every hour over 10 time-points.

\section{STATISTICAL ANALYSIS OF FLUORESCENCE BETWEEN VENUS AND EFORRED}

The optical density readings for each time point were processed using Microsoft Excel 2013. For each fluorescence protein, the average absorbance value (from three biological replicates with three technical replicates each) and corresponding and standard error at every timepoint was calculated. The significance between related data ( $\mathrm{p}$-value) of each protein at each time-point was calculated using the paired sample Student's t-test (Microsoft Excel 2013).

\section{RESULTS AND DISCUSSION}

\section{SUCCESSFUL CONSTRUCTION OF REPORTER PLASMIDS} k14.1_Venus, k14.1_eforRED AND pcat_Venus

The plasmid k14.1 (Juhas et al. 2014), also known as pSB1K3(FRTK), was linearised by PCR to produce an amplicon of $\sim 5000 \mathrm{bp}$ (Figure 1(A)). In this study, the mutant Green Fluorescent Protein (GFP) of Aequorea victoria was chosen as the reporter protein because it contains the F46L mutation that accelerates the oxidation of the chromophore at $37^{\circ} \mathrm{C}$ (Nagai et al. 2002).

The Venus amplicon of 1000 bp (Figure 1(B)) and the linearised k14.1 were ligated using a two-way Gibson Assembly to produce the plasmid k14.1_Venus. The Gibson Assembly master mix employs three enzymes namely T5 exonuclease, Phusion polymerase and Taq DNA ligase. At $50^{\circ} \mathrm{C}$, T5 exonuclease degrades the 5' end of dsDNA to generate 3' ssDNA and the enzyme is quickly degraded. The homologous region ends of DNA fragments hybridise to each other at the 3' end and Phusion polymerase adds dNTPs to fill in the missing nucleotides followed by sealing of the DNA gap by Taq DNA ligase (Gibson et al. 2009).

The ligated product was transformed into competent E. coli and selected on kanamycin. Kanamycin resistant colonies that emit bright yellow fluorescence when viewed using UV light indicated the presence of the recombinant plasmid k14.1_Venus (Figure 1(C)). Plasmid k14.1_Venus was later harvested and its sequence was validated by DNA sequencing.

The plasmid k14.1_Venus was then amplified and the Venus gene was excluded using the openk14.1_Venus_ eforRED primers (Table 2) to enable substitution with 
A

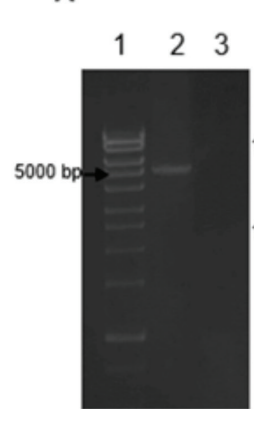

B

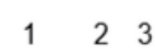

C

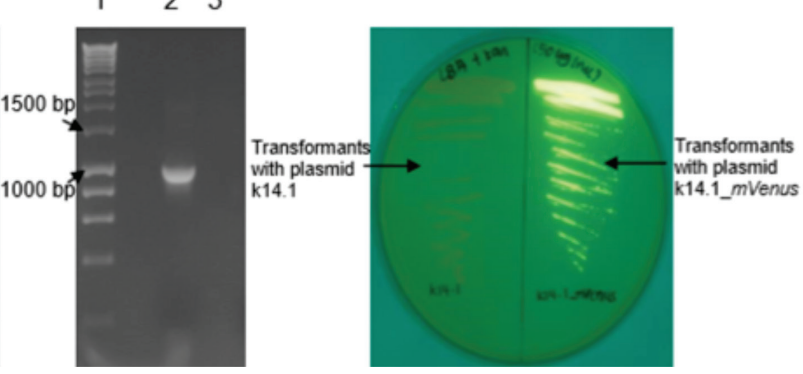

FIGURE 1. The development of the yellow reporter plasmid, k14.1_Venus

(A) Amplification of linearised k14.1 using the k14.1 primers. Lane 1: Hyperladder 1 kb (Bioline); Lane 2: Linearised k14.1 amplicon and Lane 3: Negative control. (B) The Venus amplicon generated using the Venus primers. Lane 1: Hyperladder $1 \mathrm{~kb}$ (Bioline); Lane 2: Venus amplicon and Lane 3: Negative control and (C) Comparison of yellow fluorescence emitted by transformants with k14.1 and k14.1_Venus

the eforRED gene. The expected size of the linearised plasmid is $5328 \mathrm{bp}$ and a band sized in between $5000 \mathrm{bp}$ and 6000 bp was observed (Figure 2(A)). The eforRED fragment ( 1001 bp) (Figure 2(B)) was amplified using the eforRED primers (Table 2). These fragments were joined using the Gibson protocol and the recombinant plasmid (k14.1_eforRED) was transformed into E. coli before validating by colony PCR. Colony PCR showed that the amplified eforRED gene had the expected size of 1001 bp (Figure 2(C)). The plasmid was extracted and the DNA sequence was verified by sequencing.

The plasmid k14.1_Venus was linearised to exclude the kan cassette and to create a ligation site for the insertion of the cat gene using the openk14.1_Venus_cat primers. The expected size of the linearised k14.1_Venus backbone without kan is $\sim 4682 \mathrm{bp}$ while the cat gene amplified from pLysS had the expected size of $\sim 920$ bp (Figure 2(E)). Both k14.1_Venus (without kan) and cat were assembled
A

$\begin{array}{lll}1 & 2 & 3\end{array}$

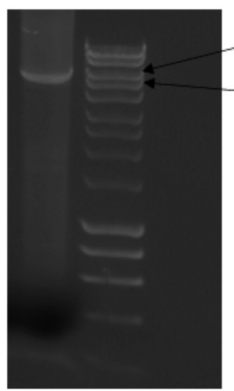

D

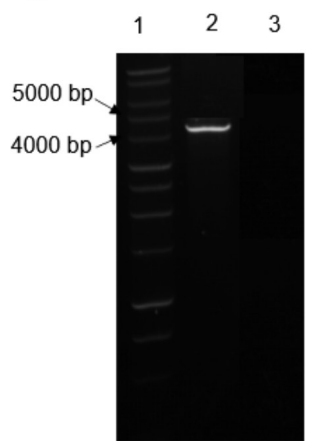

B

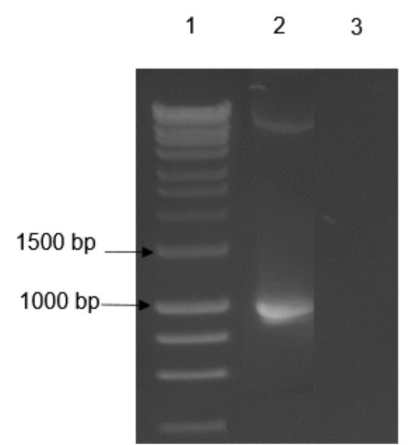

$\mathbf{E}$

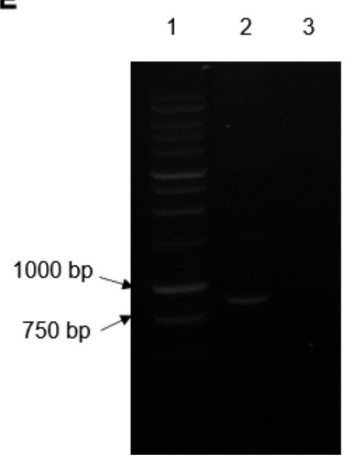

C

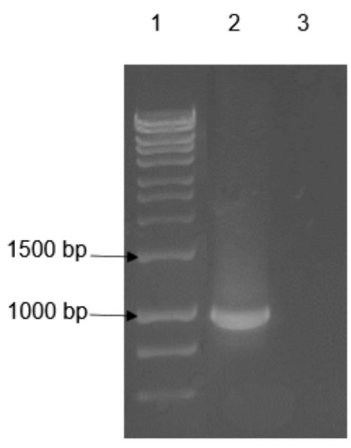

$\mathbf{F}$

1 2

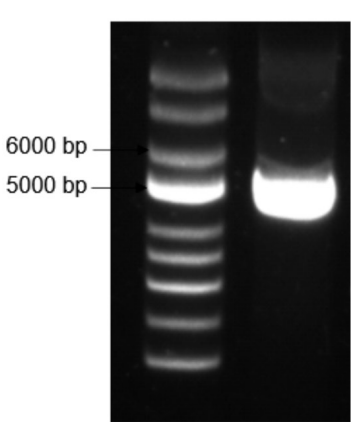

FIGURE 2. The construction and validation of k14.1_eforRED and pcat_Venus

(A) Linearised k14.1 amplicon without Venus using the openk14.1_Venus_efor RED primers. Lane 1: Linearised k14.1 amplicon; Lane 2: Hyperladder 1 kb (Ladder) and Lane 3: Negative control. (B) The eforRED amplicon amplified using the eforRED primers. Lane 1: Hyperladder $1 \mathrm{~kb}$ (Bioline); Lane 2: eforRED amplicon and Lane 3: Negative control. (C) Colony PCR of the transformant with k14.1_eforRED. Lane 1: Hyperladder $1 \mathrm{~kb}$ (Bioline); Lane 2: Amplified eforRED gene using the eforRED primers and Lane 3: Negative control. (D) The k14.1_Venus backbone without kan amplified with openk14.1_Venus_cat primers. Lane 1: 1 kb DNA Ladder (Promega); Lane 2: k14.1_Venus without kanamycin and Lane 3: Negative control. (E) The cat amplicon generated using the cat primers. Lane 1: $1 \mathrm{~kb}$ DNA Ladder (Promega); Lane 2: cat amplicon and Lane 3: Negative control and (F) Extracted pcat_Venus. Lane 1: Supercoiled DNA Ladder (NEB) and Lane 2: pcat_Venus 
and transformed into E. coli. The extracted plasmid DNA had the expected size of $\sim 5482$ bp (Figure 2(F)) and presence of the pcat_Venus was validated by sequencing. Both k14.1_eforRED and pcat_Venus were then used for the construction of DRS using the Red recombineering and FLP/FRT recombination techniques.

RED RECOMBINEERING FOR CHROMOSOMAL INTEGRATION AND FLP/FRT RECOMBINATION FOR ANTIBIOTIC GENE REMOVAL

Chromosomal integration of heterologous genes in a surrogate host has been reported to increase recombinant protein production. In an earlier report, the chromosomal integration strategy was adopted to integrate Zymomonas mobilis genes involved in the ethanol production pathway, into the $a d h E$ operon of $E$. coli $\mathrm{K} 12$ to create ethanologenic $E$. coli strains. The promoterless cassette was used to disrupt the $a d h E$ operon to create an operon fusion and relied on the $a d h E$ promoter to increase the production of ethanol (Martinez-Morales et al. 1999). In addition to E. coli, integration of genes has also been successful in $S$. cerevisiae where genes encoding for endo/exoglucanase and $\beta$-glucosidase were chromosomally inserted into the yeast host to enable the production of ethanol in media containing cellulose (Cho et al. 1999).

To allow a large DNA cassette to be integrated into the host chromosome, many different chromosomal integration methods can be employed and one such method is the Red recombinases system. The Red recombinase-based chromosomal integration strategy was shown previously to introduce large DNA constructs into the $E$. coli chromosome (Kuhlman \& Cox 2010; Sabri et al. 2013; Ublinskaya et al. 2012). One of these strategies is the two-step Redrecombinase integration method that requires the insertion of a landing pad on chromosome, followed by excision of the pad via I-SceI (yeast endonuclease) cleavage and subsequently, second integration of the gene of interest into the integrated pad (Kuhlman \& Cox 2010). However, the I-SceI cleavage site is not found in the E. coli genome (Sabri et al. 2013). In our study, we employed the onestep Red recombineering technique that targets the $E$. coli chromosomal regions to develop the DRS (Juhas et al. 2014). This technique is similar to the knock-in/knock-out (KIKO) vector-based method (Sabri et al .2013) but simpler. Figure 3 depicts the key steps involved in the development of the DRS.

Our study compared two previously identified nonessential E. coli chromosomal insertion target sites, flgG (Juhas \& Ajioka 2015a) and motA (Juhas \& Ajioka 2015b). In this work, the recombineering cassettes $\mathrm{fgG}$ eforRED and motA-Venus were generated with the flgG and $m o t A$ flanking primers using PCR where a $66 \mathrm{bp}$ region (homologous $\lg G$ or $\operatorname{mot} A$ region) was added to the 5 , and 3 ' ends of the recombineering cassettes, respectively, to facilitate homologous recombination (Figure 3(A) and 3(B)). Each cassette harbours the reporter gene regulated by a constitutive penicillinase promoter, pPen from Bacillus licheniformis (Yansura \& Henner 1984) and an antibiotic resistance gene, flanked by the FLP Recognition Target (FRT) (Figure 3(B)).
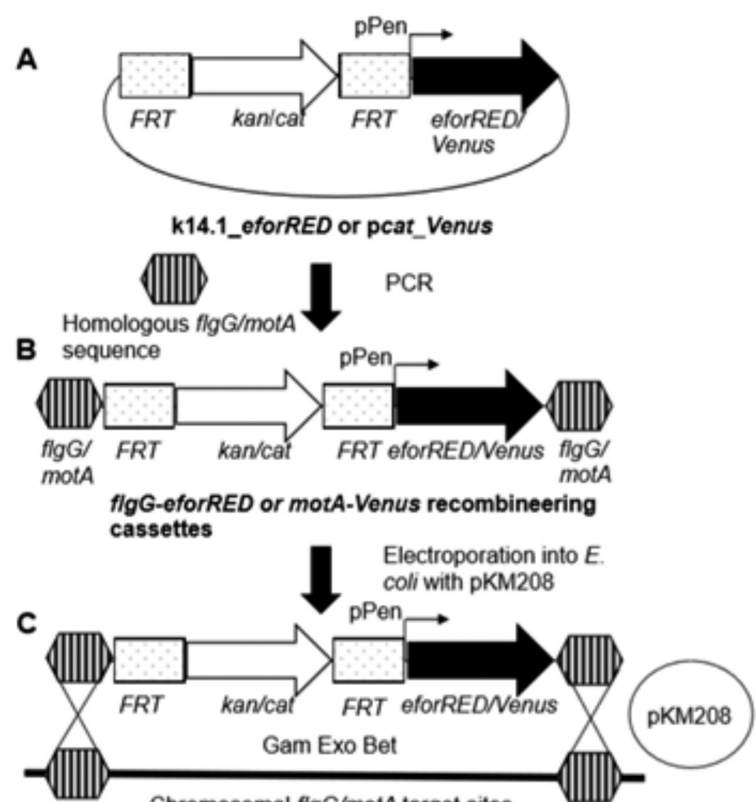

Chromosomal flgG/motA target sites.
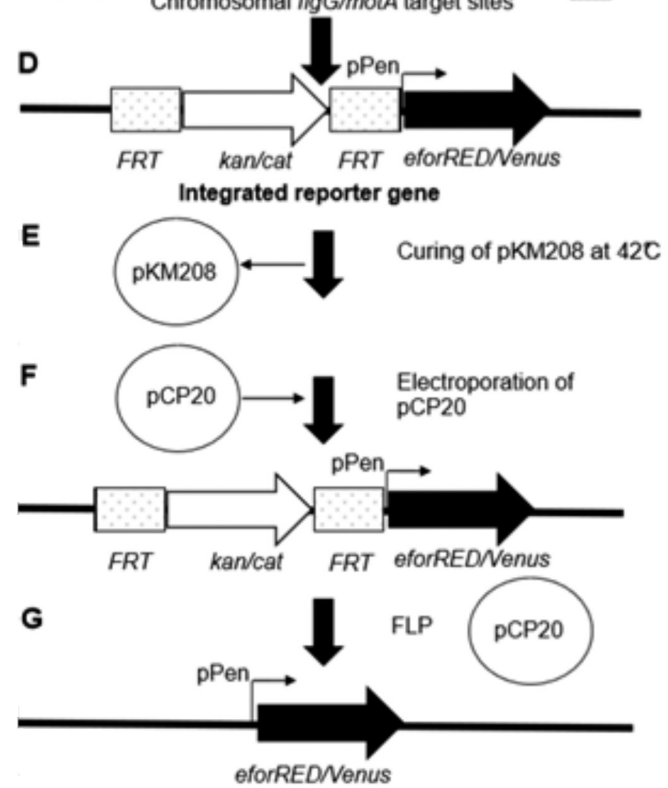

H

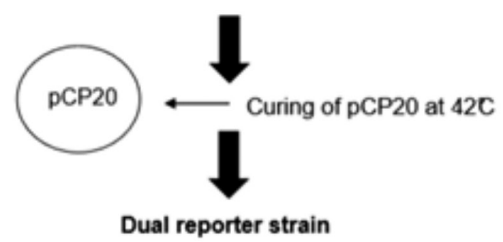

FIGURE 3. Key steps in developing the marker-free dual reporter strain

(A) Amplification of flgG-eforRED and motA-Venus recombineering cassettes from k14.1_eforRED and pcat_Venus, respectively. (B) The cassettes consist of reporter and antibiotic resistance genes and were electroporated into $E$. coli with pKM208 upon induction with $1 \mathrm{mM}$ IPTG. (C) Homologous recombination at chromosomal $\mathrm{flg} G$ or $\mathrm{motA}$ target site with the help of Gam, Exo and Bet proteins expressed by pKM208. (D) Integrated recombineering cassette (E) Curing of the thermosensitive $\mathrm{pKM} 208$ at $42^{\circ} \mathrm{C}$. (F) Electroporation of pCP20 that expresses FLP constitutively to excise the antibiotic resistance gene. $(\mathrm{G})$ Removed antibiotic gene from recombineering cassette and $(\mathrm{H})$ Curing of thermosensitive pCP20 at $42^{\circ} \mathrm{C}$ to generate the dual reporter strain 
Amplification of $f g G$ eforRED and motA Venus produced fragments corresponding to the expected sizes of $\sim 3432$ bp and $\sim 3395$ bp, respectively (Figure $4)$. Approximately $4 \mu \mathrm{g}$ of DNA was electroporated into electrocompetent $E$. coli. The pKM208-plasmid borne Red recombineering system of the $\boldsymbol{\lambda}$ bacteriophage was employed in this study as the chromosomal integration strategy to allow insertion of recombineering cassettes into the E. coli chromosome. Regulated by lacZ with the induction of $1 \mathrm{mM}$ IPTG, plasmid pKM208 harbours gam, exo and bet that code for the $16 \mathrm{kDa}$ polypeptide, the $24 \mathrm{kDa}$ exonuclease Exo and the ssDNA-binding Bet (Muniyappa \& Radding 1986). Gam inhibits host RecBCD exonuclease $\mathrm{V}$ and SbcCD nuclease (Kulkarni $\&$ Stahl 1989), which would otherwise degrade the exogenous dsDNA. Then, Exo degrades a single strand of DNA of the exogenous dsDNA in entirety, generating a ssDNA (Mosberg et al. 2010) followed by the binding of Bet to ssDNA and directing the recombineering cassette to the site of integration where homologous recombination is then mediated (Datsenko \& Wanner 2000) (Figure 3(C)).

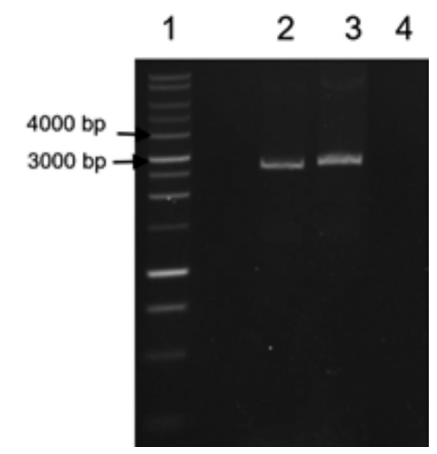

FIGURE 4. Generation of recombineering cassettes using the flg G and motA primers. Lane 1: $1 \mathrm{~kb}$ DNA Ladder (Promega); Lane 2: flg G eforRED amplicon; Lane 3: motA Venus amplicon and Lane 4: Negative control

Initially, the DRS was developed through the disruption of $f g G$ in flagellar region 1 by eforRED. Colony PCR using the flanking $f g G$ i primers showed that the $f g G$ i eforRED amplicon has the expected size of $\sim 3658$ bp whereas $E$. coli without chromosomal insertion has the expected amplified $\operatorname{flgG}$ of $\sim 963$ bp (Figure 5(A)). The plasmid pKM208 carries the pSC101 origin of replication (ori) that is thermosensitive (Murphy \& Campellone 2003) and is easily cured from the bacterial host at $42^{\circ} \mathrm{C}$ (Figure $3(\mathrm{E})$ ). The plasmid pCP20 that harbours the $S$. cerevisiae $f l p$ gene was then introduced into $E$. coli to express FLP constitutively (Figure 3(F)). Therefore, no protein induction was required for strains with pCP20. The k14.1 plasmid backbone has the FRT sites that flank the antibiotic resistance genes (kan and cat). This enables the removal of these genes via FLP/FRT recombination to generate markerfree strains with integrated reporter genes.
The FLP/FRT recombination functions well in both fungi (Bloemendal et al. 2014) and bacteria (Ishikawa \& Hori 2013). Although FLP can also be used to insert DNA into chromosomes ( $\mathrm{Gu}$ et al. 2015), the preferred direction of FLP is excision (Ringrose et al. 1998). The FRT sites normally have a minimal sequence of 5'-GAAGTTCCTATTCtctagaaaGAATAGGAACTTC-3' with two flanking sequences (5'-GAAGTTCCTATTC-3') and an 8 bp core (5'-tctagaaa-3'). The FLP protein binds to the flanking sequences and cleaves ahead of the core region (Zhu \& Sadowski 1995). This results in the excision of the antibiotic resistance gene from the integrated recombineering cassette (Figure $3(\mathrm{G})$ ).

Colony PCR using the flanking FRT primers showed that the kan knocked-out amplicon from the flgGi eforRED strain had the expected size of $\sim 112$ bp whereas the $f g G \mathrm{i}$ eforRED amplicon, in the absence of $\mathrm{pCP} 20$, was sized at between $1000 \mathrm{bp}$ and $1500 \mathrm{bp}$ (expected size of amplified kan is 1342 bp) (Figure 5(B)). Similar to pKM208, the thermosensitive $\mathrm{pCP} 20$ is cured from the bacterial host at $42^{\circ} \mathrm{C}$ (Figure $3(\mathrm{H})$ ).

The complete DRS was obtained when Venus was integrated at the motA site which was validated by PCR. The amplified motAi Venus was approximately 3519 bp whereas the non-integrated motA amplicon had the expected size of $\sim 614$ bp (Figure 5(C)). Using FLP/FRT recombination, the cat gene was removed from the Venus cassette and this was confirmed by colony PCR using the flanking FRT primers (Figure 5(D)). To further validate the accuracy of the developed dual reporter system in determining the best integration site for synthetic DNA to enable efficient protein expression, we attempted to construct a reverse reporter system (motAi eforRED and flgGi Venus-reporter genes with switched integration sites) but integration of Venus at $\operatorname{fg} G$ was unsuccessful.

In this study, the $f g G$ and $m o t A$ sites were selected as target sites for DNA insertion because they are located away from each other in different chromosomal regions (Juhas et al. 2014). This eliminates the possibility of excising the entire intervening region in the event of FLP/FRT recombination during removal of the antibiotic-resistance genes.

\section{THE E. COLI flgGi eforRED AND DUAL REPORTER MUTANT STRAINS HAVE ABOLISHED MOTILITY}

To confirm the successful integration of eforRED and Venus at the respective target sites, $f g G \mathrm{i}$ eforRED and DRS (flgGi eforRED - motAi Venus) strains were tested using the swimming assay. Both $f g G$ and motA encode for bacterial proteins that contribute towards motility and disruption of these genes could foil or reduce swimming motility (Juhas \& Ajioka 2015a, 2015b). All the reporter strains showed a reduced capacity $(p<0.001)$ to swim when compared to the parental strain E. coli E. cloni $10 \mathrm{G}$ (Table 3 ). The diameter of the swimming halo formed by the DRS is similar to the strain bearing the single insertion at flgG (Table 3). FlgG forms the basal body of the bacterial 
A

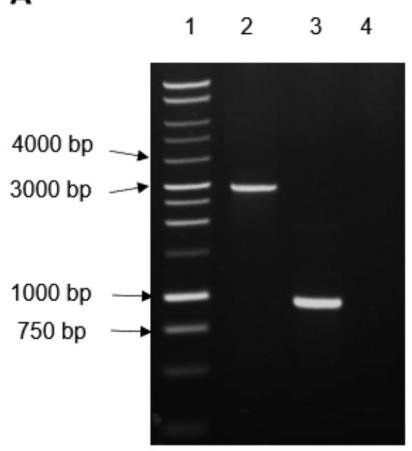

C

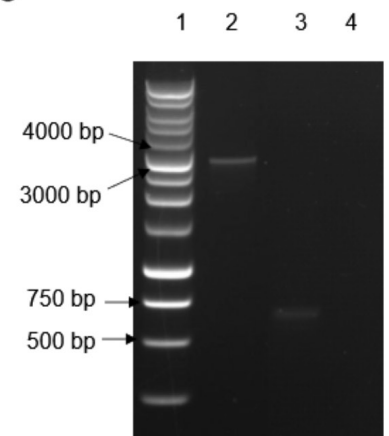

B

$\begin{array}{lllll}1 & 2 & 3 & 4 & 5\end{array}$

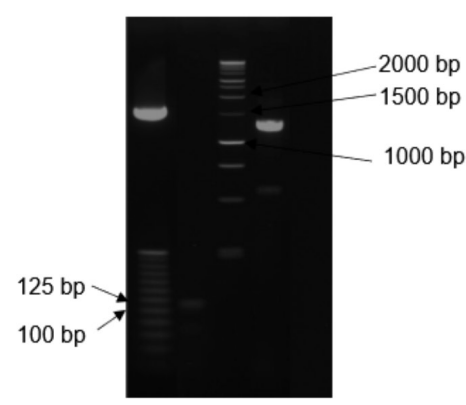

D

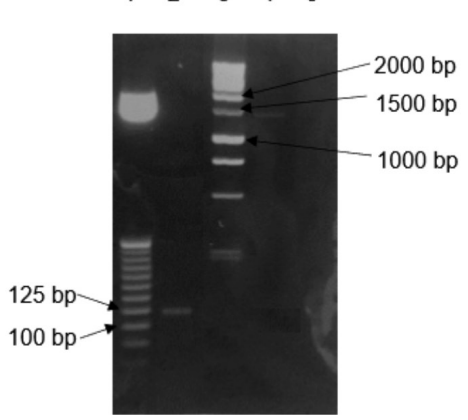

FIGURE 5. Development and validation of the dual reporter system

(A) Colony PCR of the integrated eforRED reporter gene at $f g G$ site. Lane 1: $1 \mathrm{~kb}$ DNA Ladder (Promega); Lane 2: flgGi eforRED amplicon; Lane 3: flgG amplicon and Lane 4: Negative control. (B) Colony PCR of kan knocked-out flgGi eforRED strain. Lane 1: 25 bp DNA Step Ladder (Promega); Lane 2: Flanking FRT amplicon; Lane 3: 1 kb DNA Ladder (Promega); Lane 4: Flanking FRT with kan cassette amplicon and Lane 5: Negative control (C) Colony PCR of the integrated Venus reporter gene at motA site. Lane 1: 1 kb DNA Ladder (Promega); Lane 2: motAi Venus amplicon, Lane 3: motA amplicon and Lane 4: Negative control. (D) Colony PCR of cat knocked-out flgGi eforRED motAi Venus strain. Lane 1: 25 bp DNA Step Ladder (Promega); Lane 2: Flanking FRT amplicon; Lane 3: 1 kb DNA Ladder (Promega); Lane 4: Flanking FRT with cat cassette amplicon and Lane 5: Negative control

TABLE 3. Average diameter of the swimming halo formed by E. coli and mutant strains on swimming agar

\begin{tabular}{lc}
\hline Bacterial strain & Average diameter of swimming halo formed $(\mathrm{cm}, \pm \mathrm{SE})$ \\
\hline E. coli E. cloni $10 \mathrm{G}$ & $7.9 \pm 0.07$ \\
flgGi eforRED & $0.4 \pm 0.03$ \\
Dual reporter & $0.5 \pm 0.06$ \\
\hline
\end{tabular}

flagellar rod (Macnab 2003) while MotA normally forms a hetero-hexameric complex with MotB (MotA tetramer and MotB dimer) to become the stator which will then interact with the rotor to drive the rotation of the bacterial flagellar motor (Takekawa et al. 2016). Hence, disruption of the associated genes resulted in the loss of flagellar function.

CHROMOSOMAL INSERTION DOES NOT CAUSE METABOLIC BURDEN UPON THE HOST AND THE MOTA FLAGELLAR GENE IS THE BETTER INTEGRATION TARGET SITE COMPARED TO $f g G$

Overexpression of heterologous proteins usually contribute heavy metabolic burden to the recombinant host (Bhattacharya \& Dubey 1995; Carneiro et al. 2013) leading to cell growth arrest and subsequently, reduced heterologous protein synthesis (Bentley \& Kompala 1990; Glick 1995). Although many different strategies have been employed to improve recombinant protein production, this was achieved at the expense of reduced cell biomass (Carneiro et al.2013). The dual reporter system developed in this study was severely impeded in terms of motility (Table 3 ) but the growth rate of this strain was unaffected when compared to the parental strain (Figure 6(A)).

The reporter proteins EforRED and Venus have maximum absorption at $589 \mathrm{~nm}$ (Alieva et al. 2008) and $515 \mathrm{~nm}$ (van der Krogt et al. 2008), respectively. The optical densities of the two chromoproteins as expressed by the DRS were evaluated at the respective excitation wavelengths (Figure 6(B)). The absorbance values for Venus were significantly higher compared to EforRED $(p<0.05)$ over the period of evaluation. Juhas and Ajioka (2015a, 2015b) also reported that transcription from $m o t A i$ was 4 times higher compared to $f g G i$. Furthermore, it 
A

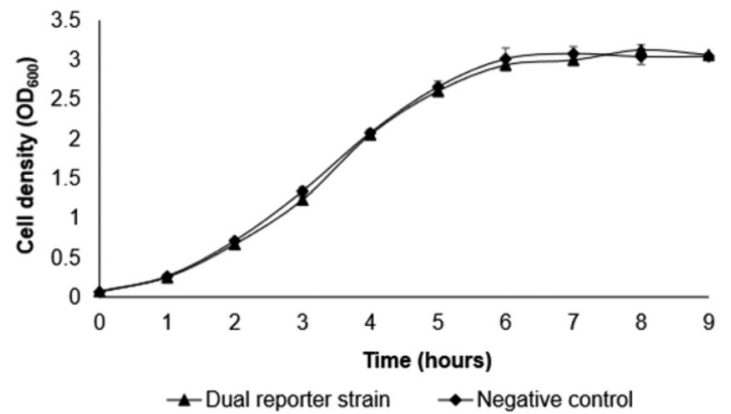

B

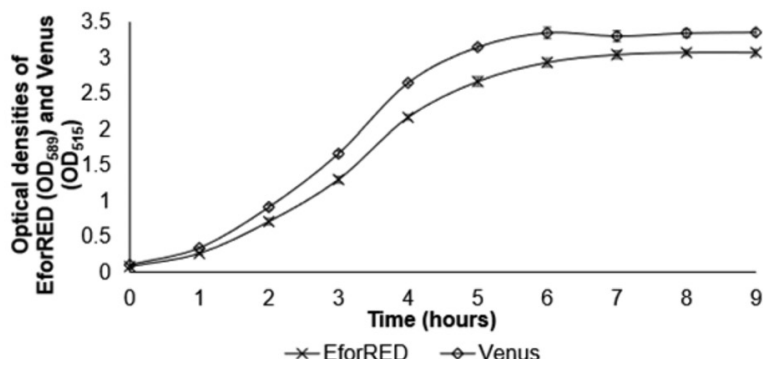

FIGURE 6. Real-time measurement of bacterial cell density $\left(\mathrm{OD}_{600}\right)$, Venus $\left(\mathrm{OD}_{515}\right)$ and EforRED $\left(\mathrm{OD}_{589}\right)$ over 10 time-points

(A) The cell density $\left(\mathrm{OD}_{600}\right)$ of the dual reporter strain and negative control and (B) Comparison of the optical densities of Venus $\left(\mathrm{OD}_{515}\right)$ and EforRED $\left(\mathrm{OD}_{589}\right)$ in the dual reporter strain. Values represent the means and standard errors from three biological replicates with three technical replicates each

was also reported that the primary criterion in selecting the best integration site was the transcription rate at the targeted sites (Bai Flagfeldt et al. 2009). Although the reverse system was not successfully built to further validate the integration sites, the results as obtained by the dual reporter system is adequate for the context of this study. Taken together, the genes inserted into the bacterial chromosome and subsequent expression (as represented by the fluorescence of the reporters) did not present any metabolic burden onto the host. This agrees with the reports by Juhas and Ajioka (2015a, 2015b) and Sabri et al. (2013) that hosts with chromosomally inserted genes had unaffected growth. Since Venus was inserted at motA whereas eforRED was integrated at $\lg G$, we propose that the motA flagellar gene is the better target locus for future synthetic biology applications.

\section{CONCLUSION}

Flagellar genes are suitable non-essential target genes for chromosomal insertion in the design of an E. coli-based synthetic biology toolkit. The $\lg G$ and motA target loci were compared using the DRS (flgGi eforRED - motAi Venus) that expressed the EforRED and Venus reporter proteins. Gene disruption at the flagellar region completely abolished motility of the host but did not affect its growth.
The fluorescence emitted by Venus was significantly higher than EforRED, indicating that motA is the more suitable target locus compared to $f g G$. This study rationalises the choice of target site for chromosomal insertion for future synthetic biology applications.

\section{ACKNOWLEDGEMENTS}

We gratefully acknowledge Universiti Kebangsaan Malaysia for funds under the ICONIC Programme (ICONIC-2013-004) awarded to K-LW and the Commonwealth Scholarship Commission (CSC) for the Commonwealth Split-Site $\mathrm{PhD}$ Award 2015 granted to C-HY during his placement at Cambridge University.

\section{REFERENCES}

Ajikumar, P.K., Xiao, W., Tyo, K.E.J., Wang, Y., Simeon, F., Leonard, E., Mucha, O., Phon, T.H., Pfeifer, B. \& Stephanopoulos, G. 2010. Isoprenoid pathway optimization for Taxol precursor overproduction in Escherichia coli. Science 330(6000): 70-74.

Alieva, N.O., Konzen, K.A., Field, S.F., Meleshkevitch, E.A., Hunt, M.E., Salih, A. \& Matz, M.V. 2008. Diversity and evolution of coral fluorescent proteins. PLOS ONE 3(7): 1-12.

Atsumi, S., Hanai, T. \& Liao, J.C. 2008. Non-fermentative pathways for synthesis of branched-chain higher alcohols as biofuels. Nature 451: 86-89.

Bai Flagfeldt, D., Siewers, V., Huang, L. \& Nielsen, J. 2009. Characterization of chromosomal integration sites for heterologous gene expression in Saccharomyces cerevisiae. Yeast 26(10): 545-551.

Bentley, W.E. \& Kompala, D.S. 1990. Optimal induction of protein synthesis in recombinant bacterial cultures. Annals of the New York Academy of Sciences 589(1): 121-138.

Bhattacharya, S.K. \& Dubey, A.K. 1995. Metabolic burden as reflected by maintenance coefficient of recombinant Escherichia coli overexpressing target gene. Biotechnology Letters 17(11): 1155-1160.

Bloemendal, S., Löper, D., Terfehr, D., Kopke, K., Kluge, J., Teichert, I. \& Kück, U. 2014. Tools for advanced and targeted genetic manipulation of the $\beta$-lactam antibiotic producer Acremonium chrysogenum. Journal of Biotechnology 169: 51-62.

Carneiro, S., Ferreira, E.C. \& Rocha, I. 2013. Metabolic responses to recombinant bioprocesses in Escherichia coli. Journal of Biotechnology 164(3): 396-408.

Chang, M.C.Y., Eachus, R.A., Trieu, W., Ro, D.K. \& Keasling, J.D. 2007. Engineering Escherichia coli for the production of functionalized terpenoids using plant P450s. Nature Chemical Biology 3: 274-277.

Cho, K.M., Yoo, Y.J. \& Kang, H.S. 1999. ס-Integration of endo/exo-glucanase and $\beta$-glucosidase genes into the yeast chromosomes for direct conversion of cellulose to ethanol. Enzyme and Microbial Technology 25(1-2): 23-30.

Cunningham, D.S., Koepsel, R.R.,Ataai, M.M.\& Domach, M.M. 2009. Factors affecting plasmid production in Escherichia coli from a resource allocation standpoint. Microbial Cell Factories 17: 1-17.

Datsenko, K.A. \& Wanner, B.L. 2000. One-step inactivation of chromosomal genes in Escherichia coli K-12 using PCR products. Proceedings of the National Academy of Sciences USA 97(12): 6640-6645. 
Davis, M.W. ApE: A plasmid editor. 2012. Version 2.0.49. Utah: University of Utah.

Gibson, D.G., Young, L., Chuang, R., Venter, J.C., Hutchison, C. \& Smith, H.O. 2009. Enzymatic assembly of DNA molecules up to several hundred kilobases. Nature Methods 6(5): 343-345.

Glick, B.R. 1995. Metabolic load and heterologous gene expression. Biotechnology Advances 13(2): 247-261.

Gu, P., Yang, F., Su, T., Wang, Q., Liang, Q. \& Qi, Q. 2015. A rapid and reliable strategy for chromosomal integration of gene(s) with multiple copies. Scientific Reports 5(9684): 1-9.

Hanahan, D., Jessee, J. \& Bloom, F.R. 1991. Plasmid transformation of Escherichia coli and other bacteria. Methods in Enzymology 204: 63-113.

Haseloff, J. \& Ajioka, J. 2009. Synthetic biology: History, challenges and prospects. Journal of the Royal Society, Interfacelthe Royal Society 6(6): 389-391.

Ishikawa, M. \& Hori, K. 2013. A new simple method for introducing an unmarked mutation into a large gene of non-competent gram-negative bacteria by FLP/FRT recombination. BMC Microbiology 13(86): 1-10.

Juhas, M. 2016. On the road to synthetic life: The minimal cell and genome-scale engineering. Critical Reviews in Biotechnology 36(3): 416-423.

Juhas, M. \& Ajioka, J.W. 2015a. Identification and validation of novel chromosomal integration and expression loci in Escherichia coli flagellar region 1. PLOS ONE 10(3): 1-13.

Juhas, M. \& Ajioka, J.W. 2015b. Flagellar region 3b supports strong expression of integrated DNA and the highest chromosomal integration efficiency of the Escherichia coli flagellar regions. Microbial Biotechnology 8(4): 726-738.

Juhas, M., Evans, L.D.B., Frost, J., Davenport, P.W., Yarkoni, O., Fraser, G.M. \& Ajioka, J.W. 2014. Escherichia coli flagellar genes as target sites for integration and expression of genetic circuits. PLOS ONE 9(10): 1-7.

Juhas, M., Davenport, P.W., Brown, J.R., Yarkoni, O.\& Ajioka, J.W. 2013. Meeting report: The Cambridge BioDesign TechEvent - Synthetic Biology, a new 'Age of Wonder'? BTJ-FORUM. pp. 761-763.

Keasling, J.D. 2008. Synthetic biology for synthetic chemistry. ACS Chemical Biology 3: 64-76.

Kuhlman, T.E. \& Cox, E.C. 2010. Site-specific chromosomal integration of large synthetic constructs. Nucleic Acids Research 38(6): 1-10.

Kulkarni, S.K. \& Stahl, F.W. 1989. Interaction between the $s b c C$ gene of Escherichia coli and the gam gene of phage $\lambda$. Genetics 253: 249-253.

Macnab, R.B. 2003. How bacteria assemble flagellar. Annual Review of Microbiology 57(1): 77-100.

Martinez-Morales, F., Borges, A.C., Martinez, A., Shanmugam, K.T. \& Ingram, L.O. 1999. Chromosomal integration of heterologous DNA in Escherichia coli with precise removal of markers and replicons used during construction. Journal of Bacteriology 181(22): 7143-7148.

Mosberg, J.A., Lajoie, M.J. \& Church, G.M. 2010. Lambda Red recombineering in Escherichia coli occurs through a fully single-stranded intermediate. Genetics 186(3): 791-799.

Muniyappa, K. \& Radding, C.M. 1986. The homologous recombination system of phage $\lambda$ : Pairing activities of $\beta$ protein. Journal of Biological Chemistry 261: 7472-7478.

Murphy, K.C.\& Campellone, K.G. 2003.Lambda Red-mediated recombinogenic engineering of enterohemorrhagic and enteropathogenic E. coli. BMC Molecular Biology 4: 11.
Nagai, T., Ibata, K., Park, E.S., Kubota, M., Mikoshiba, K. \& Miyawaki, A. 2002. A variant of yellow fluorescent protein with fast and efficient maturation for cell-biological applications. Nature Biotechnology 20(1): 87-90.

Ringrose, L., Lounnas, V., Ehrlich, L., Buchholz, F., Wade, R. \& Stewart, A.F. 1998. Comparative kinetic analysis of FLP and cre recombinases: Mathematical models for DNA binding and recombination. Journal of Molecular Biology 284(2): 363-384.

Silva, F., Queiroz, J.A. \& Domingues, F.C. 2012. Evaluating metabolic stress and plasmid stability in plasmid DNA production by Escherichia coli. Biotechnology Advances 30(3): 691-708.

Sabri, S., Steen, J.A., Bongers, M., Nielsen, L.K. \& Vickers, C.E. 2013. Knock-in/knock-out (KIKO) vectors for rapid integration of large DNA sequences, including whole metabolic pathways, onto the Escherichia coli chromosome at well-characterised loci. Microbial Cell Factories 12(60): $1-14$.

Takekawa, N., Terahara, N., Kato, T. \& Gohara, M. 2016. The tetrameric MotA complex as the core of the flagellar motor stator from hyperthermophilic bacterium. Scientific Reports 6(31526): 1-8.

Tyo, K.E., Ajikumar, P.K. \& Stephanopoulos, G. 2009. Stabilized gene duplication enables long-term selection-free heterologous pathway expression. Nature Biotechnology 27(8): 760-765

Ublinskaya, A.A., Samsonov, V.V., Mashko, S.V. \& Stoynova, N.V. 2012. A PCR-free cloning method for the targeted Q80 Int-mediated integration of any long DNA fragment, bracketed with meganuclease recognition sites, into the Escherichia coli chromosome. Journal of Microbiological Methods 89: 167-173.

van der Krogt, G.N., Ogink, J., Ponsioen, B. \& Jalink, K. 2008. A comparison of donor-acceptor pairs for genetically encoded FRET sensors: Application to the Epac cAMP sensor as an example. PLoS ONE 3(4): 1-9.

Yansura, D.G. \& Henner, D.J. 1984. Use of the Escherichia coli lac repressor and operator to control gene expression in Bacillus subtilis. Proceedings of the National Academy of Sciences USA 81(2): 439-443.

Zhu, X.D. \& Sadowski, P.D. 1995. Cleavage-dependent ligation by the FLP recombinase. Journal of Biological Chemistry 270(39): 23044-23054.

Chee-Hoo Yip, Kiew-Lian Wan \& Sheila Nathan*

School of Biosciences and Biotechnology

Faculty of Science and Technology

Universiti Kebangsaan Malaysia

43600 UKM Bangi, Selangor Darul Ehsan

Malaysia

Chee-Hoo Yip, Orr Yarkoni Mario Juhas \& James Ajioka

Department of Pathology, Tennis Court Road

University of Cambridge

CB2 1QP Cambridge

United Kingdom

*Corresponding author; email: sheila@ukm.edu.my

Received: 29 March 2018

Accepted: 28 August 2018 